\title{
KARAKTERISTIK PASIEN FRAKTUR FEMUR AKIBAT KECELAKAAN LALU LINTAS PADA ORANG DEWASA
}

\author{
Astri Doris \\ Akademi Keperawatan Kesdam I/BB Padang \\ Email : Astridoris20@gmail.com
}

\begin{abstract}
ABSTRAK
Salah satu akibat dari kecelakaan lalu lintas yang paling sering adalah Fraktur Femur. Fraktur ini dapat menyebabkan perdarahan, cedera organ dalam, infeksi luka, sindrom pernafasan serta dapat kecacatan. Tujuan penelitian ini untuk mengetahui karakteristik dari Fraktur pada orang dewasa di wilayah kerja puskesmas pasar baru bayang pesisir selatan. Penelitian ini merupakan penelitian deskritif yang dilakukan pada 83 pasien fraktur femur akibat kecelakaan lalu lintas pada orang dewasa, selama bulan Januari 2020 dengan menggunakan data sekunder yaitu catatan rekam medis pasien di puskesmas Pasar baru bayang pesisir selatan. Dari hasil data penelitian didapatkan 83 pasien fraktur femur dan sebagian besar adalah pria sebanyak 68 orang (82\%), dari kelompok umur sebagian besar usia 16-40 tahun sebanyak 54 orang (65\%). Dari 83 sampel didapatkan bahwa sebagian besar adalah fraktur tertutup sebanyak 52 kasus $(62,7 \%)$ dan untuk lokasi fraktur terbanyak pada daerah tengah yaitu sebanyak 48 kasus (58\%). Karakteristik dari fraktur femur pada orang dewasa akibat kecelakaan lalu lintas di wilayah kerja puskesmas Pasar baru bayang pesisir selatan lebih banyak terjadi pada pria, dengan kelompok usia paling banyak 16-40 tahun, jenis fraktur terbanyak adalah fraktur tertutup, serta lokasi terbanyak pada daerah tengah.
\end{abstract}

Kata kunci: Kecelakaan lalu lintas, Fraktur femur, Fraktur tertutup

\begin{abstract}
One of the most frequent traffic accidents is the Femur Fracture. This fracture can cause bleeding, internal organ damage, wound infection, respiratory infections and disability. The purpose of this study was to study the characteristics of fractures in adults in the working area of the new Pasar Puskesmas in the southern shore of Pesisir. This study was a descriptive study conducted on 83 patients who had a traffic accident in an adult, during January 2020 using secondary data, namely the patient's medical record in the Pasar Baru shadow south coast. From the results obtained 83 patients with femoral fractures and most of them are 68 men (82\%), from the largest age group 16-40 years as many as 54 people (65\%). Of the 83 samples obtained, most were closed fractures in 52 cases (62.7\%) and for the most fracture sites in the middle area, 48 cases (58\%). Characteristics of fractures in adults due to traffic accidents in the working area of puskesmas. Pasar shadow new South shore is more common in men, with a group of at most 16-40 years, most types of fractures are in closed fractures, as well as the most locations in the middle area.
\end{abstract}

Keywords: Traffic accident, Femur fracture, Closed fracture 


\section{PENDAHULUAN}

Kecelakaan lalu lintas merupakan penyebab kematian nomor delapan dan merupakan penyebab kematian teratas pada penduduk usia 15 - 29 tahun di dunia dan jika tidak ditangani dengan serius pada tahun 2030 kecelakaan lalu lintas akan meningkat menjadi penyebab kematian kelima di dunia. Setiap tahun terdapat 1,24 juta orang yang meninggal disebabkan oleh kecelakaan lalu lintas, sedangkan $20-50$ juta orang lainnya mengalami disabilitas akibat kecelakaan lalu lintas.

Kasus fraktur femur merupakan yang paling sering yaitu sebesar 39\% diikuti fraktur humerus (15\%), fraktur tibia dan fibula (11\%), dimana penyebab terbesar fraktur femur adalah kecelakaan lalu lintas yang biasanya disebabkan oleh kecelekaan mobil, motor, atau kendaraan rekreasi $(62,6 \%)$ dan jatuh dari ketinggian $(37,3 \%)$ dan mayoritas adalah pria $(63,8 \%)$. Insiden fraktur femur pada wanita adalah fraktur terbanyak kedua (17,0 per 10.000 orang per tahun) dan nomer tujuh pada pria (5,3 per orang per tahun). Puncak distribusi usia pada fraktur femur adalah pada usia dewasa (15 - 34 tahun) dan orang tua (diatas 70 tahun).

Fraktur femur adalah diskontinuitas dari femoral shaft yang bisa terjadi akibat trauma secara langsung (kecelakaan lalu lintas atau jatuh dari ketinggian), dan biasanya lebih banyak dialami laki laki dewasa. Apabila seseorang mengalami fraktur pada bagian ini, pasien akan mengalami perdarahan yang banyak dan dapat mengakibatkan penderita mengalami syok. Fraktur femur dapat menyebabkan komplikasi, morbiditas yang lama dan juga kecacatan apabila tidak mendapatkan penanganan yang baik. Komplikasi yang timbul akibat fraktur femur antara lain perdarahan, cedera organ dalam, infeksi luka, emboli lemak, sindroma pernafasan. Banyaknya komplikasi yang ditimbulkan diakibatkan oleh tulang femur adalah tulang terpanjang, terkuat, dan tulang paling berat pada tubuh manusia dimana berfungsi sebagai penopang tubuh manusia. Selain itu pada daerah tersebut terdapat pembuluh darah besar sehingga apabila terjadi cedera pada femur akan berakibat fatal.

Angka kecelakaan lalu lintas dan insiden patah tulang di Dunia cukup tinggi yang akan terus mengalami peningkatan seiring dengan bertambahnya jumlah kendaraan masyarakat setiap tahunnya. Indonesia pada umumnya serta Bali pada khususnya merupakan salah satu konsumen kendaraan terbesar di dunia. Hingga saat ini data epidemiologis mengenai patah tulang femur di Indonesia sangatlah minim. Data epidemiologis tersebut sangat pernting untuk mengetahui seberapa besar gambaran patah tulang femur dan distribusinya di Indonesia, dan Bali pada khususnya.

\section{METODE}

Penelitian ini merupakan penelitian deskritif. Populasinya adalah semua pasien dewasa dengan fraktur femur akibat kecelakaan lalu lintas yang dirawat di wilayah kerja puskesmas Pasar baru bayang pesisir selatan pada tahun 2020. Sampel penelitian dikumpulkan menggunakan teknik total sampling yang diperoleh dari data sekunder rekam medis di wilayah kerja puskesmas Pasar baru bayang pesisir selatan dan didapatkan 83 sampel.

\section{HASIL}

Selama periode penelitian, jumlah sampel yang diperoleh yaitu sebanyak 83 sampel dimana sebagian besar berjenis kelamin lakilaki yaitu sebanyak 68 sampel $(82 \%)$ dan wanita sebanyak 15 sampel (18\%). Selain dibagi berdasarkan jenis kelamin, sampel juga digolongkan berdasarkan kelompok umur tertentu yakni, kelompok usia 16-40 tahun yaitu sebanyak 54 (65\%) orang, kelompok usia 31-40 tahun sebanyak 15 (18 \%) orang dan kelompok 41-50 tahun sebanyak 14 (17\%) orang. 
Data mengenai jenis fraktur diperoleh dari pembacaan rekam medis pasien, diperoleh jenis fraktur tertutup sebanyak 52 (62,7\%) orang dan jenis fraktur terbuka $31(37,3 \%)$ orang. Dari data tersebut sebanyak 17 $(20,4 \%)$ fraktur berlokasi di proksimal, 48 (58\%) fraktur berlokasi di tengah dan sebanyak $18(21,6 \%)$ fraktur berlokasi di distal.

Tabel 1

Karakteristik Fraktur Femur Akibat

Kecelakaan Lalu Lintas pada Orang

Dewasa mempunyai perilaku mengemudi lebih cepat dibandingkan dengan wanita.

Usia pasien fraktur femur akibat kecelakaan usia 16-40 tahun sebanyak 54 orang (65\%), pasien berusia 31-40 tahun sebanyak 15 orang (18\%), dan pasien berusia 41-50 tahun

sebanyak 14 orang (17\%). Pasien dengan rentang umur 16-40 tahun paling banyak mengalami fraktur femur akibat kecelakaan lalu lintas dikarenakan usia tersebut merupakan usia produktif dan biasanya pada usia tersebut sebagian besar memiliki mobilitas yang cukup tinggi untuk beraktivitas di luar ruangan.

\begin{tabular}{|l|l|}
\hline Karakteristik & $\mathbf{N}=\mathbf{8 3}$ \\
\hline Umur: & \\
\hline $16-40$ & $54(65 \%)$ \\
$31-40$ & $15(18 \%)$ \\
$41-50$ & $14(17 \%)$ \\
\hline Jenis kelamin: & \\
\hline Pria & $68(82 \%)$ \\
\hline Wanita & $15(18 \%)$ \\
\hline Jenis Fraktur: & \\
\hline Fraktur Tertutup & $52(62,7 \%)$ \\
\hline Fraktur Terbuka & $31(37,3 \%)$ \\
\hline Lokasi Fraktur: & \\
\hline Proksimal & $17(20,4 \%)$ \\
\hline Tengah & $48(58 \%)$ \\
\hline Distal & $18(21,6 \%)$ \\
\hline
\end{tabular}

Berdasarkan 83 sampel penelitian pasien fraktur femur akibat kecelakaan lalu lintas, kasus pasien fraktur femur jenis fraktur tertutup lebih banyak dibandingkan fraktur terbuka yaitu sebanyak 52 kasus (62,7\%), sedangkan $\mathrm{j}$ enis fraktur terbuka hanya sebanyak 31 kasus $(37,3 \%)$.

Untuk lokasi fraktur femur sama halnya engan jenis fraktur, dimana satu pasien dapat mengalami fraktur di lokasi yang berbeda. aka dari itu jumlah sampel yang digunakan ntuk lokasi fraktur femur ini adalah sebanyak 83 sampel. Berdasarkan 83 sampel penelitian tersebut, lokasi fraktur femur daerah proksimal sebanyak 17 kasus $(20,4 \%)$, pada daerah

\section{PEMBAHASAN}

Pada penelitian ini didapatkan didapatkan sampel penelitian pasien fraktur femur akibat kecelakaan lalu lintas. Sebagian besar sampel adalah pria 68 (82\%) dan sisanya wanita 15 (18\%). Data tersebut menunjukan bahwa jumlah pasien fraktur femur akibat kecelakaan lalu lintas pada pria dua kali lipat dari pasien perempuan. Hal ini sesuai dengan penelitian yang dilakukan di Pakistan oleh Obaidur Rahman pada tahun 2013, menunjukan bahwa mayoritas pasien fraktur femur akibat kecelakaan dialami oleh pria sebanyak $63,8 \%$. Tingginya kasus fraktur femur pada pria diakibatkan karena pria lebih aktif dan lebih banyak melakukan aktivitas di luar rumah seperti bekerja, olahraga, serta rata-rata pria tengah sebanyak 48 kasus (58\%), dan pada daerah distal sebanyak 18 kasus $(21,6 \%)$.

Lokasi terbanyak terdapat pada daerah tengah, sesuai dengan penelitian yang dilakukan oleh Salminen dkk pada tahun 2000, dimana fraktur femur pada daerah tengah atau diafisis sebesar 79\%. Hal ini terjadi karena daerah diafisis atau tengah mengalami tekanan dan energi tinggi dari trauma yang terjadi sehingga menyebabkan daerah diafisis lebih sering mengalami fraktur. ${ }^{3}$ Kecelakaan lalu lintas merupakan penyebab tersering dari terjadinya fraktur pada daerah diafisis atau tengah ini, selain akibat jatuh dari ketinggian. 


\section{SIMPULAN}

Dari penelitian ini dapat disimpulkan bahwa karakteristik fraktur femur pada orang dewasa akibat kecelakaan lalu lintas di wilayah kerja puskesmas Pasar baru bayang pesisir selatan adalah lebih sering terjadi pada pria (68\%), kelompok usia 16-40 tahun (65\%), berjenis fraktur tertutup $(62,7 \%)$, dan lokasi pada daerah tengah $(58 \%)$.

\section{SARAN}

Kekurangan Penelitian adalah sedikitnya variabel yang diteliti sehingga cakupan karakteristik yang didapatkan pada penelitian ini masih kurang luas dan mendalam. Perlu dilakukan penelitian lebih lanjut mengenai fraktur femur untuk mengetahui faktor resiko terkait.

\section{DAFTAR PUSTAKA}

Adnan, Rana Muhhamad (2012). Frequency Of Femoral

Fractures;Comparison In Patients Less Than And More Than 40 Years of Age. Professional.

Audige L, (2005) A concept for the validation of fracture classifications. $\mathrm{J}$ Orthop Trauma.

Kemenkes RI (2012), Profil Kesehatan Indonesia.

Obaidur Rahman dkk (2013). Pattern of Femoral Fractures. Journal of Rawalpindi Medical College (JRMC). 
